\title{
Site of conversion of carotene into vitamin $A$ in the rat: further studies on aqueous dispersions administered intravenously
}

\author{
BY N. A. WORKER \\ Biochemistry Department, Massey Agricultural College (University of New Zealand), \\ Palmerston North, New Zealand \\ (Received 24 August 1956)
}

In earlier reports from this laboratory it was noted that in the rat the formation of vitamin A from carotene, administered intravenously as an aqueous dispersion, was unaffected by complete removal of the liver, stomach, small intestine, large intestine, pancreas, kidneys, adrenals and gonads (McGillivray, Thompson \& Worker, r956; Worker, 1956). Similarly it was shown that the amount of vitamin A appearing after injection of carotene was little affected by activity of the thyroid (McGillivray et al. r956). These results were regarded as support for the earlier conclusion of Bieri \& Pollard (1954), with which Kon, McGillivray \& Thompson (1955) agreed, 'that perhaps many tissues possess the ability to convert carotene'. The possibility still remained, however, as suggested by Kon et al. (I955), that the lungs were specifically involved in the breakdown of carotene to vitamin A. It was thought desirable, therefore, that this possibility should be further investigated. The present paper describes the results of this work, together with results of investigating the effect of decapitation on the conversion of carotene into vitamin $\mathrm{A}$.

\section{EXPERIMENTAL}

General. The rats used in these experiments were inbred albinos from the Massey College colony, partially deficient in vitamin A and weighing between 200 and $300 \mathrm{~g}$. The methods and materials were essentially similar to those described in previous communications by McGillivray et al. (1956) and by Worker (1956), with the following additions.

\section{Surgical procedure in the rat}

Removal of the lungs. For anaesthesia a combination of veterinary Nembutal (Abbott Laboratories Ltd, London), injected subcutaneously, and diethyl ether was used. First, the trachea was exposed and a cannula of plastic tubing $(2 \mathrm{~mm}$ external diameter) inserted and connected to a manually operated respirator containing pure oxygen. Next, the abdomen was opened by ventral midline and left and right lateral incisions as near as possible to the ribs, and the pleural cavity by two parallel incisions on either side of the sternum. At the same time artificial respiration was applied, with the aid of an assistant, by means of the respirator. Successive lobes of lung tissue were then quickly tied off and completely removed. Finally, $0.4 \mathrm{ml}$. of a dispersion of carotene $(\mathrm{I} \mathrm{mg} / \mathrm{ml}$.) in a $20 \%(\mathrm{v} / \mathrm{v})$ solution in water of Tween 40 (polyoxyethylene- 
sorbitan monopalmitate, Atlas Powder Co., Wilmington, Delaware) and $0.1 \mathrm{ml}$. of a $I$ in 30,000 solution of adrenaline were injected directly into the vena cava and blood samples were taken by cardiac puncture almost 5 min later (as the action of the heart began to weaken).

Removal of the head. Although there was no convincing evidence to suggest that any of the organs and tissues of the head or neck were specifically involved in the breakdown of injected carotene it was thought advisable, for the sake of completeness, to check this point. A collar of fur was first cut from around the neck of the anaesthetized animal. The left carotid artery was dissected out, tied and cut, and the left jugular vein was then similarly treated. Next the right carotid artery was tied and cut and then the right jugular vein. The whole head was then severed below the larynx and the stump swabbed liberally with a $I$ in 30,000 solution of adrenaline. 'Two small arteries lying dorsally on either side of the spinal column were quickly clamped, the animal was opened and an injection was given into the vena cava, as described above. Blood samples were obtained by cardiac puncture 5 min later.

In both series of experiments livers as well as blood were taken for assay.

RESULTS

\section{Effect of removing the lungs}

The results presented in Table I (Exp. I) show that there was no significant difference between the amount of vitamin $A$ formed in intact animals after injection of carotene and the amount formed in animals from which all functional lung tissue had been removed, plasma vitamin $\mathrm{A}$ alcohol levels of the groups increasing from the control level of $\mathrm{I} 7 \mu \mathrm{g} / 100 \mathrm{ml}$. to $39 \mu \mathrm{g}$ and $43 \mu \mathrm{g} / \mathrm{I} 00 \mathrm{ml}$, , respectively, within $5 \mathrm{~min}$. Liver levels of vitamin A from treated groups, on the other hand, showed no increase over the control group owing no doubt to the short time involved.

\section{Table I. Appearance of carotene and vitamin $A$ in the blood and livers of rats 5 min after} injection of $400 \mu \mathrm{g}$ of carotene in Tween 40

\begin{tabular}{|c|c|c|c|c|c|c|c|c|c|c|c|c|}
\hline \multirow[b]{3}{*}{$\begin{array}{l}\text { Exp. } \\
\text { no. }\end{array}$} & \multirow{2}{*}{\multicolumn{2}{|c|}{ Rats }} & & \multicolumn{4}{|c|}{ Dose } & & \multicolumn{3}{|c|}{ Total liver content } \\
\hline & & & & \multicolumn{2}{|c|}{ Vehicle } & \multicolumn{2}{|c|}{ Substance } & \multicolumn{2}{|c|}{ Blood plasma } & & \multicolumn{2}{|c|}{ Vitamin A } \\
\hline & $\begin{array}{l}\text { No. } \\
\text { used }\end{array}$ & Sex & Treatment & Nature & $\begin{array}{c}\text { Amount } \\
\text { (ml.) }\end{array}$ & Nature & $\begin{array}{c}\text { Amount } \\
(\mu \mathrm{g})\end{array}$ & $\begin{array}{c}\text { Carotene } \\
(\mu \mathrm{g} / 100 \mathrm{ml} .)\end{array}$ & $\begin{array}{c}\text { alcohol } \\
(\mu \mathrm{g} / \mathrm{roo} \mathrm{ml} .)\end{array}$ & $\begin{array}{c}\text { Carotene } \\
(\mu g)\end{array}$ & $\begin{array}{c}\text { Alcohol } \\
(\mu \mathrm{g})\end{array}$ & $\begin{array}{l}\text { Ester } \\
(\mu \mathrm{g})\end{array}$ \\
\hline$I$ & 3 & M. & None & None & 一 & None & - & o & 17 & Trace & 0.4 & 0.8 \\
\hline & 3 & M. & None & $\begin{array}{l}\text { Tween } \\
\text { dispersion }\end{array}$ & 0.4 & Carotene & 400 & 4500 & 39 & 'Trace & 0.5 & 0.7 \\
\hline & 9 & $\begin{array}{l}\text { M. } \\
\text { and } \\
F .\end{array}$ & $\begin{array}{l}\text { Lungs } \\
\text { removed }\end{array}$ & $\begin{array}{l}\text { Tween } \\
\text { dispersion }\end{array}$ & 0.4 & Carotene & 400 & 5000 & 43 & Trace & 0.7 & $I \cdot r$ \\
\hline 2 & 2 & $\mathrm{~F}$. & None & None & - & None & - & & 19 & Trace & 0.6 & 0.8 \\
\hline & I & $F$ & None & $\begin{array}{l}\text { Tween } \\
\text { dispersion }\end{array}$ & 0.4 & Carotene & 400 & 6800 & 46 & Trace & 0.7 & x.o \\
\hline & 5 & $\begin{array}{l}\text { M. } \\
\text { and } \\
\text { F. }\end{array}$ & $\begin{array}{l}\text { Head } \\
\text { removed }\end{array}$ & $\begin{array}{l}\text { Tween } \\
\text { dispersion }\end{array}$ & 0.4 & Carotene & 400 & 7600 & 40 & Trace & 0.6 & 0.9 \\
\hline
\end{tabular}




\section{Effect of removing the head}

The results in Table I (Exp. 2) provide clear evidence that no part of the head or neck is in any way specifically involved in the conversion of injected carotene into vitamin A, blood levels of vitamin A alcohol within 5 min of injection showing an increase from $19 \mu \mathrm{g} / \mathrm{ro0} \mathrm{ml}$. to a mean level of $40 \mu \mathrm{g} / \mathrm{I00} \mathrm{ml}$., a level similar to that of the treated groups in the previous experiment.

\section{DISCUSSION}

In earlier experiments (McGillivray et al. 1956; Worker, 1956) it was shown that removal of the liver, viscera or thyroid had no influence on the animal's ability to convert injected carotene into vitamin A. The aim of the present experiments was to determine what effect, if any, removal of the lungs or the head and neck had on this function. Neither removal produced any demonstrable effect. It would thus appear certain, both from this evidence and from that submitted previously by Bieri \& Pollard (1954), Kon et al. (1955), McGillivray et al. (1956) and Worker (1956), that the ability to convert injected carotene is an attribute not of any one tissue or organ, but of many, or perhaps of all, cells. This belief is further supported by the results in this laboratory of preliminary in vitro experiments, showing that many tissues, including blood, possess the ability to form small amounts of vitamin $A$ on incubation with carotene in Tween dispersed in physiological saline. Further experiments along these lines are at present being planned; it is hoped some insight into the mechanism of conversion may be gained from them.

\section{SUMMARY}

I. The effects of lung removal and decapitation on the conversion into vitamin A of intravenously administered aqueous dispersions of carotene have been studied in the rat.

2. Within $5 \mathrm{~min}$ of injection of $400 \mu \mathrm{g}$ of carotene in Tween $4^{\circ}$ the amount of vitamin A circulating in the blood of animals without lungs was the same as the amount circulating in the blood of intact control animals.

3. Similarly, within $5 \mathrm{~min}$ of injection of carotene the amount of vitamin A formed by decapitated animals was the same as the amount formed by normal animals.

4. From these results, and from those presented previously from this laboratory and by other workers, it is concluded that the ability to convert injected carotene into vitamin $\mathrm{A}$ is not a function of any one organ or tissue, but of many.

The results of this investigation form a section of a thesis submitted in partial fulfilment of the requirements for the degree of Ph.D. of the University of New Zealand. The author wishes to express his thanks to Dr W. A. McGillivray of the Biochemistry Department, Massey College, for advice and helpful criticism, and to the Department of Scientific and Industrial Research for a grant towards the investigation. The technical assistance of Miss Fay Frecklington is gratefully acknowledged. 
REFERENCES

Bieri, J. G. \& Pollard, C. J. (1954). Brit. F. Nutr. 8, 32.

Kon, S. K., McGillivray, W. A. \& Thompson, S. Y. (1955), Brit. F. Nutr. 9, 244.

McGillivray, W. A., Thompson, S. Y. \& Worker, N. A. (1956). Brit. F. Nutr. 10, 126.

Worker, N. A. (1956). Brit. F. Nutr. 10, 169.

\title{
The utilization of aqueous dispersions of carotene by rats and of carotene and vitamin $A$ by lactating goats
}

\author{
By W. A. McGILLIVRAY and N. A. WORKER \\ Biochemistry Department, Massey Agricultural College (University of New Zealand), \\ Palmerston North, New Zealand \\ (Received 24 August 1956)
}

It is now generally accepted that orally administered carotene is converted into vitamin $A$ in the intestinal wall of all species of higher animal so far investigated (see, for example, review by Kon \& Thompson, I95I). Conflicting reports are still appearing, however, about the utilization of carotene given parenterally. In previous communications (Kon, McGillivray \& Thompson, 1955; McGillivray, Thompson \& Worker, 1956) we have shown, in agreement with earlier reports by other workers (e.g. Bieri \& Pollard, I954; Bieri, I955a), that carotene administered intravenously as an aqueous dispersion to rats or rabbits is converted into vitamin $A$ at a site other than the intestine. About the true site of conversion Worker $(1956,1957)$ has established, as originally suggested by Bieri \& Pollard (I954) and later supported by Kon et al. (I955) and McGillivray et al. (1956), that no organ is specifically involved and that conversion can probably occur in any tissue. If this is so, some conversion into vitamin $A$ of aqueous carotene dispersions administered by parenteral routes other than the intravenous might be expected, and various workers have in fact claimed restoration of growth or other disappearance of vitamin A-deficiency signs after intramuscular, intraperitoneal or subcutaneous injection of various carotene dispersions (e.g. Bieri \& Sandman, I95I; Lease, Lease, Steenbock \& Baumann, r942; Tomarelli, Charney \& Bernhart, 1946). It therefore seemed that a comparison, as indicated by hepatic vitamin A stores, of the efficiency of conversion into vitamin A of aqueous carotene dispersions administered by various routes, and further investigations more detailed than earlier ones of some of the factors influencing the utilization of intravenously injected carotene dispersions, might provide additional information about the mechanism and nature of the processes involved.

After the claim by Sobel, Rosenberg \& Engel (1952) that the intravenous administration of an aqueous dispersion of vitamin A to lactating cows resulted in a marked increase in the vitamin A level of their milk, the effect of aqueous dispersions of vitamin A alcohol and ester and of carotene injected intravenously into lactating goats was investigated, as was also the effect of similar dispersions injected directly into the mammary gland. 